\title{
Under the Volcano \\ Stabilizing the Early Javanese State in an Unstable Environment
}

\author{
Jan Wisseman Christie
}

\section{Introduction}

Over the millennia the impact of human beings on the landscape and environment of Java has been profound. But the converse has also been true: the environment of the island - both climatic and geological - has shaped the lives of those who dwell there. Given the proximity of Java's active volcanoes to densely populated areas of the island, the devastation they have caused has at times been significant. Yet, possibly because of the relative geological quiescence of the twentieth century, many historians have tended to discount the role played by eruptions and earthquakes in shaping the early political and social history of the island. ${ }^{1}$

Memories of the destructive force of the volcanoes are, however, preserved in Javanese chronicles, and these were often invested with political significance. The massive eruption of the volcano Merapi at the heart of central Java late in 1822, perceived as an omen of the coming of the mythic 'Just King' in a time of famine and oppression, helped to precipitate the Java War of 1825 (Carey 1986:131). Eighteenth-century central Java perceived the ash-rains and eruptions of the volcanoes Merapi and Prahu in the 1760 and 1770 s as signs heralding collapse of the state (Ricklefs 1974:186). The Babad Tanah Djawi states that the death of the great seventeenth-century king Sultan Agung was marked by Merapi's rumblings (Ricklefs 1974:18), and, according to the Babad ing Sangkala, that volcano's major eruption of 1672 not only killed many outright, but presaged far greater political and military calamities (Ricklefs 1978:181). The fifteenth century Pararaton lists eight eruptions and one major earthquake between 1311 and 1486, most invested with significance in the world of men (Phalgunadi 1996). These histories suggest that for centuries the Javanese had suffered periodic bouts of geological instability, and that throughout that time, supernatural agency was ascribed to them.

Investigating the geological upheavals of earlier periods is more difficult. No chronicles have survived from the first millennium, and the courtly kakawin

1 See the article by Anthony Reid in this volume.

(C) JAN WISSEMAN CHRISTIE, 2015 | DOI 10.1163/9789004288058_005

This is an open access chapter distributed under the terms of the Creative Commons Attribution-

Noncommercial 3.0 Unported (CC-BY-NC 3.0) License. 
literature of the time, based on Indian originals, was too distanced from events in Java to provide more than a hint that eruptions and earthquakes were perceived to be the results of divine activity. Archaeology and geology provide some clues to the geological stresses of the times, but few concerning their impact on the people living in close proximity to the volcanoes. Of the records produced in Java during later first millennium, the only survivors are inscriptions written on stone and metal, most of which were produced by the state of Mataram. Since almost all of these inscriptions are either religious documents or tax charters, the information they provide is indirect. Much, however, can be gleaned from the changing patterns of political and religious activity they record, and these changes suggest that the state of Mataram, and its people, were forced to cope with even greater geological disasters than were their successors. The fact that the state survived says much for its resilience.

\section{Early Mataram and Its Century of Turbulence}

Mataram was one of the great historic polities of maritime Southeast Asia. Its wealth rested upon a combination of agricultural abundance and extensive trade (Wisseman Christie 1998, 1999). The number and size of its stone-built temple complexes, and the quantities of gold, silver and textiles that were transferred at ceremonies marking the benefice grants that were made for the support of these religious foundations attest to this wealth. ${ }^{2}$ The state's agrarian abundance came at a price, however, since it owed the richness of its soils to the active volcanoes that surrounded its most densely populated areas. Although Mataram survived for more than three centuries, it did not remain the same. Over that period it first expanded rapidly; then met with disaster and contracted sharply, moving its centre several hundred kilometers to the east; and then re-stabilized for a time before finally breaking down.

The state of Mataram was founded early in the eighth century, probably in the northern part of the Kedu plain of central Java between the volcanic Dieng massif and the volcanoes Merbabu and Merapi. A few inscriptions of the later ninth and early tenth centuries identify the founder of the state as ratu Sañjaya, whose reign began in $716 \mathrm{CE}$ (Damais 1951:42-63). Given the paucity of data, little can be said at this point about the earliest phase of the state. However,

2 Gifts to the hundreds of witnesses attending a series of benefice ceremonies held in the 870 s and 88 os for the support of one temple, for instance, received almost 1.75 kilograms of gold, 0.25 kilograms of silver, more than 800 pieces of cloth, large numbers of iron tools and other items, and substantial amounts of food. See Wisseman Christie (1996: 275-276). 
most of the reigns of the first century and a half following Mataram's foundation seem to have been relatively long and successful. By the end of the eighth century the state had expanded to the south and east in central Java, encircling Merapi and Merbabu, to encompass the area around modern Yogyakarta and Prambanan (Wisseman Christie 2001:32-38). The first break in this series of stable reigns seems to have occurred in $847 \mathrm{CE}$, and it initiated a century of intermittent political upheaval. Piecing together information scattered amongst the surviving inscriptions - particularly that provided by the Wanua Tĕngah III inscription $^{3}$ - it is possible to assemble a preliminary outline of the political events that occurred between 847 and 948 CE.

This period of repeated instability was initiated when rake Pikatan dyah Saladū mounted the throne in $847 \mathrm{CE}$. His tenure on the throne was contested, and his reign was relatively short. When he died in $855 \mathrm{CE}$, the throne passed to rake Kayuwangi dyah Lokapāla. Rake Kayuwangi apparently oversaw a rapid expansion of the state to the east, taking control of the heartland of east Java by about $860 \mathrm{CE}$. Rake Kayuwangi's death early in $885 \mathrm{CE}$, however, precipitated a period of increasing turbulence. Three rulers succeeded to the throne within less than two years, before the state descended into civil war (Wisseman Christie 2001:38-50). Finally, late in $894 \mathrm{CE}$, the state was reunited when rake Wungkal Humalang took the throne. Following his death in $898 \mathrm{CE}$, rake Watukura dyah Balitung mounted the throne. In about $910 \mathrm{CE}$ Balitung died and was succeeded in a regular manner by his heir-apparent, rake Hino $p u$ Dakșa. Dakșa was, in turn, succeeded in about $919 \mathrm{CE}$ - again apparently peacefully. However, the next ruler, who came to the throne in around $927 \mathrm{CE}$, was displaced before the end of that year. The new ruler held the throne for only about a year before being succeeded by his heir-apparent, rake Hino pu Sinḍok, who remained on the throne until about $948 \mathrm{CE}$. The significant aspect of this last transition, aside from the brevity of his predecessor's reign, is the fact that from the time Sindok took over, in 929 CE, Mataram's inscriptions were issued solely in east Java. Although the state continued to exist for more than a century, it issued no inscriptions in central Java after $928 \mathrm{CE}$. Something drastic appears to have happened to cause the state to abandon its established core region. The fact that no other political power seems to have filled the void in central Java suggests that the cataclysm was natural rather than man-made.

The surviving inscriptions, and their changing contents and patterns of distribution, provide an insight - though admittedly an oblique one - into the stresses, both man-made and geological, which helped to shape the political

3 This inscription provides a dated king list for part of this period (Kusen 1988-9; Wisseman Christie 2001). 
and religious ideology of this early Javanese state, and which provided, to a degree, a template for its successors. The nature of these stresses, and the state's responses to them, form the focus of the discussion below.

\section{Evidence of Geological Stress}

As noted above, the challenges faced by Mataram between the mid-ninth and mid-tenth centuries were great enough to cause considerable - though episodic - political instability. This turbulence reached a peak in $928 \mathrm{CE}$, when the state's political and economic heartland in the densely populated and agriculturally rich lowlands surrounding Merapi in central Java was apparently abandoned, along with the majority of its monumental temples and religious foundations.

A major eruption, or series of eruptions, of Merapi, at the heart of the central Javanese portion of the state is the most probable cause of this turmoil, and physical evidence seems to confirm this suggestion. ${ }^{4}$ Deep layers of lahar, or volcanic mud, built up in relatively rapid succession in low-lying areas to the south and southeast of the mountain. ${ }^{5}$ Temples such as Sambi Sari and Kedulan, built during the ninth century in these low-lying areas, have been discovered buried under almost seven metres of lahar. These volcanic mud flows may also account for the large number of unrecovered hoards of small valuable objects - gold and silver currency, jewelry, military accoutrements, salvers and bowls, statues, ritual items and so forth - that have been found in the same region. The most spectacular of these finds, the Wonoboyo treasure, appears to comprise the entire contents of the strong room of a branch of the royal family. ${ }^{6}$ Areas of central Java to the west of the mountain seem to have

4 There is some debate concerning the exact timing and nature of this volcanic activity, arising from an early eleventh century date suggested by R.W. van Bemmelen and some of his predecessors (Bemmelen 1956), based upon what was then known of the history of early Java. Given difficulties in precision of geological dating, more recent studies have tended not to question that original dating (Newhall et al. 2000; Gomez et al. 2010).

5 There appear to have been at least five separate flows of volcanic mud, possibly similar in the pattern to the more recent build-up of volcanic deposits on parts of the Caribbean island of Montserrat: the surface of each layer of lahar in central Java appears to have been exposed for long enough to become weathered, but most not for long enough for significant plant colonization and soil formation to have occurred (Newhall et al. 200o: fig. 4/E1; personal observation during field surveys, 1975-1999).

6 For the Wonoboyo treasure, see Kusumohartono (1993) and Wahyono (1994); for other currency finds, see Wicks (1986) and Wisseman Christie (1996). 
been affected at much the same time, apparently by air-borne ejecta: the ninth- and early tenth-century occupation layer at Borobudur, to the west of Merapi, is sealed by up to half a metre of volcanic ash.

This major eruption was not Merapi's first during this period. The sealed occupation layer at Borobudur is interrupted by three or four narrow bands of ash, indicating that there had been at least three separate, smaller episodes of volcanic activity in the later decades of occupation at the site (Wisseman Christie 2001:47). Damage caused by accompanying earthquakes may explain not only the half-completed reliefs on the base of Borobudur - interrupted when the sagging monument was rapidly shored up by encasing the base with a broad, stabilizing foot - but also the fact that most of the other temples of central Java were apparently under continual repair and reconstruction until the point when most were seemingly abandoned. The repeated shoring-up of temples suggests that problems caused by periodic earth tremors may have been significant.

Considering the degree to which political instability in central Java during later centuries is known to have been provoked or exacerbated by eruptions of Merapi and accompanying earthquakes, it would not be surprising if a far more catastrophic series of volcanic eruptions and damaging earthquakes caused considerable turmoil during the later ninth and early tenth centuries. A more detailed review of the inscriptions produced in central and east Java during this period provides some support for this supposition. The inscriptions also provide clues to the responses of the early Javanese to the geological disturbances of the times.

\section{Religious Responses to Geological Stress}

Several important strands can be identified amongst the ideological responses of the early Javanese to periods of instability. The rulers who mounted the throne of Mataram immediately following, or within a few years of, periods of turmoil - and thus presumably facing problems of consolidating their hold on the throne - tended to issue large numbers of tax charters endowing religious foundations. The most notable of these rulers were rake Kayuwangi, Balitung and Sindiok during the ninth and tenth centuries, and Airlangga early in the eleventh century. The nature of the religious foundations they endowed, however, changed over this time. The surviving inscriptions and religious structures suggest that, by the middle of the ninth century, religious activity supported by the state had already begun to shift from Buddhism - dominant in the lowlands during the later eighth and early ninth centuries - to forms of 
Śaivism focused largely upon the slopes of volcanoes close to the heart of the state in central Java, and the volcanic uplands of Dieng and Ungaran in central Java and of Malang in east Java. Although existing Buddhist foundations were periodically re-endowed, most of the new foundations and endowments of the later ninth century were at least nominally Śaivite in nature. The Indian god Śiva found a ready niche in the fertile, volcanic interior of Java, as the ascetic god of destruction and re-creation, lord of fertility and of ghosts, associated with fire, mountains and the source of sacred water (Daniélou 1964:16,188-231).

By the beginning of the tenth century boundaries were becoming increasingly blurred between Śaivite cults (including those focused on Agastya and Ganeśa) and the cult of deified ancestors - apparently linked to the spirits of the volcanoes - and to water temples. ${ }^{7}$ Religious activity also became increasingly focused upon ascetic and tantric practices (Zoetmulder 1968:287-288), and the major gods - both Hindu and Buddhist - were increasingly merged with each other. The general trend appears to have been away from the religious eclecticism of earlier centuries, and towards religious syncretism.

Particularly prominent amongst developments in religion at the state level was the increasing emphasis upon the veneration of ancestor spirits, and the linking of these spirits with Hindu deities. During the Mataram period there appear to have been two classes of ancestor spirit: the primordial; and the proximate - those who had been prominent figures of the state during their lifetimes. The primordial ancestors were generally referred to as sang hyang (holy spirits). ${ }^{8}$ They were apparently as powerful as the imported Hindu and Buddhist deities (Zoetmulder 1968:269), and some were clearly identified with mountains (Zoetmulder 1968:307ff).

The more proximate ancestors were normally addressed as dewata ${ }^{9}$ and identified as lumah (lying) at specified sanctuaries. The relationship between the newly or historically deified dead (the dewata) and the major Hindu gods and goddesses (referred to as bhațāra and bhațāri) was apparently that of association. They often shared the same holy places, and these ancestors were venerated in conjunction with the Hindu gods - during the later ninth and tenth centuries mainly manifestations of Śiva. Ancestor kings played a

7 Wisseman Christie (1992:19-22); Degroot (2008).

8 Hyang is the general, indigenous term for the divine (Zoetmulder 1982:659).

9 Dewata is a term borrowed from Sanskrit, which was used in Old Javanese of this period both to denote some gods and also divine ancestors (Zoetmulder 1982:398). In Old Javanese inscriptions, however, the term was used solely to designate figures of importance in the state who had achieved apotheosis after death (Damais 1970:989). 
central role in the 'myth' of the state that was constructed during this period, and appeals to these ancestors appear to have increased during periods of instability. With this in mind, a reconsideration of the inscriptions may provide insight into the geological conditions under which the state of Mataram evolved.

\section{Reconsidering Mataram's Century of Turbulence}

As noted above, the first clearly recorded change in Mataram's internal political climate occurred in $847 \mathrm{CE}$, when rake Pikatan took the throne. Although he was a member of the royal family of some importance, ${ }^{10}$ his accession was not uncontested. Towards the end of his reign, having been forced to suppress an armed attempt to oust him, he moved the palace to Madang in Mamrati. ${ }^{11}$ This move was apparently designed to deal with political unease: similar 'freshstart' relocations are recorded in the histories of both this and subsequent Javanese states.

Rake Kayuwangi, who succeeded to the throne in $855 \mathrm{CE}$, both consolidated and expanded the state, taking control of the heartland of east Java by about 860 CE (Wisseman Christie 2001:42-45). His twenty-year reign - from which over sixty inscriptions have survived - was not, however, without internal strains. It is probably not a coincidence that the earliest surviving inscription from his reign, the metric Old Javanese Śiwagrha inscription of $856 \mathrm{CE}$, was a eulogy dedicated to his recently deceased predecessor. The inscription summarizes the life of this 'Śaivite king', emphasizing his generosity as a builder of religious foundations, his successful defence of the state, and his establishment of a new palace at Madang. Since he had appeared prominently as a patron of the Buddhist temple Plaosan Lor in the 830 and 840 s, he seems also to have changed religion. ${ }^{12}$ In death rake Pikatan was linked to a Śiva-lingga, the heart-stone (těas) in an Abode of Śiva, at the centre of a temple complex equipped with platforms for ascetic practices and a sacred bathing place, where a tañjung tree was planted as a place of manifestation of holy [ancestor] spirits (sang hyang), in association with the bhațāra, the god Śiva (De Casparis 1956:280-330).

10 He appears prominently in the Plaosan Lor inscriptions of the 830 s and $840 \mathrm{CSE}$ (De Casparis 1958).

11 See the Śiwagṛha inscription of 856 CE (De Casparis 1956:280-330; Wisseman Christie 2001:40-42).

12 See De Casparis (1958). 
The Śiwagṛha inscription is a key document for the study of the formation of Mataram's state myth. Most of the major elements of the religio-political formulation are present in the text: the foundation of the palace of Madang by a guardian king, and his subsequent apotheosis as a deified ancestor, in a temple complex dedicated to Śiva, associated with asceticism, a sacred tree and holy water. This is the earliest surviving reference in Javanese inscriptions to a deified ancestor king. From this point on, however, they multiplied rapidly.

Although construction of his funerary temple may have begun during rake Pikatan's lifetime, it was completed by his successor, rake Kayuwangi. The temple of rake Pikatan's apotheosis has tentatively been identified as the Siva temple in the major Hindu complex of Loro Jonggrang in Prambanan presumably the first structure to be built in that large complex. This identification is given further weight by the contents of a series of six benefice charters, found in the area, that were issued by rake Kayuwangi and a close relation. This series, issued between 873 and $881 \mathrm{CE},{ }^{13}$ provided support for a temple complex dominated by a Śaivite tower temple (prasāda) called Gunung Hyang or 'Holy Mountain', to which an ascetics' hermitage (kabikuan) was attached. This seems to have been the last very large temple complex to have been built in central Java. The contents of the Siwagṛha inscription suggest that it functioned as the state temple during the second half of the ninth century, linking a guardian ancestor king, in association with the god Siva, to the welfare of the state.

Gunung Hyang was not, however, the only religious foundation to have been constructed and endowed with rake Kayuwangi's support. Overlapping in time with the endowments to Gunung Hyang, another series of endowments was undertaken by rake Kayuwangi and a second close relative. This second religious foundation appears to have been very different in nature from that of Gunung Hyang. The charters of this series ${ }^{14}$ record support granted to a collection of about ten small Śaivite religious structures, including the religious house (dharmma umah) of Pastika, the sanctuary (parhyangan) of Smar, the hermitage (patapān) at Mulak, the religious foundation of Ramwi, and the tower-temples ( $p r a \bar{s} a \overline{d a}$ ) of Upit, Kwak, and Laṇ̣a, as well as those at Ruhur,

13 The Polengan series of inscriptions includes Tunhan, 873 CE; Humaṇịing, 875 CE; Jurungan, $876 \mathrm{CE}$; Haliwangbang, 877 CE; Mamali, $878 \mathrm{CE}$; and Taragal, $881 \mathrm{CE}$ (Suhadi and Soekarto 1986:2.7.1-2.7.6).

14 The Ngabean series and associated charters include Supit, 878 CE (Boechari 1986:52-53); Marsĕmu, c. 878 CE (Boechari 1986:53); Mulak I, 878 CE (Boechari 1986:28-30); Kwak I, 879 CE (Boechari 1986:30-32); Kwak II, 879 CE (Boechari 1986:32-33); Laṇạa A and B, c. 879 CE (Boechari 1986:56-57); Ra Tawun I, 881 CE (Boechari 1986:37-38); Ra Tawun II, 881 CE (Sarkar 1971:xlix); Pastika, 881 CE (Sarkar 1971:li); Ra Mwi, 882 CE (Boechari 1986:38-41). 
Tamwak, and Mataga. Some or all of these linked Śaivite holy places appear to have been located in Dieng, a region in the volcanic uplands of the Prahu massif also identified with Kailāsa, the abode of Śiva. ${ }^{15}$

At least two of these linked structures were clearly used as funerary temples. The tower-temple at Kwak had become, by around $882 \mathrm{CE}$, the pacandyan, or funerary temple, of the rake Wka, the member of the royal family who had cosponsored the series of endowments with the king. ${ }^{16}$ The religious house at Pastika was initially dedicated to the bhațāra (here apparently Śiva), ${ }^{17}$ but after the king rake Kayuwangi himself died in $885 \mathrm{CE}$, the sanctuary precincts also became the locus of the 'holy caitya (funerary shrine) for the well-being of the silunglung of the dewata (deified ancestor) lying at Pastika.'. ${ }^{18}$ In the literature of Bali a small funerary pavilion called a silunglung is mentioned, built to contain the ashes of the dead, over which the priest says his prayers (Zoetmulder 1974:186). In addition, the benefice supporting the funerary temple at Kwak owed flower offerings to the funerary temple at Pastika, ${ }^{19}$ thus preserving in death the hierarchical relations of the living.

The cohabitation - by Hindu gods and dewata - within the same sacred space is confirmed by another trend that is identifiable in charters issued after $855 \mathrm{CE}$. This was the increasing prominence of the curse formula in ceremonies for the dedication of benefices. Although earlier charters had occasionally threatened those disturbing a benefice with Hell and various unspecified punishments, imprecations had played a minor part in the records of early benefice ceremonies. But in $880 \mathrm{CE}$, towards the end of rake Kayuwangi's reign, there was at least one serous attack on the royal family. Part of the response, recorded in the benefice granted by the king in gratitude to those who had come to his family's aid, was a sharply increased emphasis on, and elaboration of, the curses pronounced against those who might undermine the throne. This first full curse text invoked the protection not only of the major and minor Hindu gods, but also of the 'celebrated ancestor spirits who protect the palace of the king of Mataram'. ${ }^{20}$ This was the first, but not the last, invocation of deified ancestor kings for the protection of the throne. It was an appeal that was to become more frequent in the inscriptions of succeeding decades, as the state entered a period of growing turbulence.

\footnotetext{
15 See the Kapuhunan inscription, $878 \mathrm{CE}$ (Sarkar 1971:xxxvii).

16 See the Landa A inscription, 882-883 CE (Boechari 1986:56-57).

17 For the Pastika inscription 881 CE, see Sarkar 1971:li.

18 Poh, 905 CE (Sarkar 1972:lxvi).

19 Inscription Kwak I, 879 CE. See note 14.

20 Wuatan Tija, 880 CE (Sarkar 1971:xlvi).
} 
After rake Kayuwangi died early in $885 \mathrm{CE}$, three rulers succeeded to the throne within less than two years. The first two are said to have been driven out of the palace, and the third to have fled. ${ }^{21}$ There followed a period of civil war that lasted for seven and a half years. It is possible that this political turmoil coincided with one of the periods of volcanic activity indicated by the ash layers at Borobudur. ${ }^{22}$ Finally, late in $894 \mathrm{CE}$, the state was reunited by a ruler who immediately asserted his legitimacy by reconfirming a grant made by a deceased predecessor lying at Layang, ${ }^{23}$ a place apparently associated with Dieng. ${ }^{24}$

Four years later, in $898 \mathrm{CE}$, rake Watukura dyah Balitung mounted the throne. Over forty inscriptions have survived from Balitung's twelve-year reign. The charters indicate that one of his first acts upon mounting the throne was to endow a series of holy places on the Dieng plateau and other volcanic massifs connected with royal ancestor spirits. He further consolidated his position by completing endowment projects of his deified predecessor, the dewata lying at Śataśrngga, 'One Hundred Peaks'. ${ }^{25}$ This holy site, named after the place where the ancestor of the Pāndawas of the Mahābhārata died, appears along with Dieng in a list of mountainous abodes of spirits. ${ }^{26}$ Balitung also added to the endowment of the funerary temple of rake Kayuwangi at Pastika, ${ }^{27}$ thus linking himself to that successful pre-civil war ruler. In addition, he endowed a series of holy water places and other sanctuaries that were associated both with volcanoes and with ancestor shrines. ${ }^{28}$ This continued the trend, begun by rake Kayuwangi, of associating ancestor kings with mountains.

By $905 \mathrm{CE}$, however, political unease appears to have returned. Balitung responded by moving the palace. ${ }^{29}$ This political malaise may have been caused by increasing geological activity - earthquakes and minor eruptions - that culminated in a moderately serious volcanic eruption in central Java. In $907 \mathrm{CE}$ Balitung was forced to create a new benefice and ancestor shrine (kamūlan) for

\footnotetext{
21 Wanua Tĕngah III, 908 CE (Djoko 1986; Wisseman Christie 2001:29-31).

22 Although no exact correlation can be proved, the Chinese ceramics found in the occupation layers between the narrow bands of ash appear to date to the late ninth and early tenth centuries (Mundardjito 1978, personal observation on field surveys 1977-99).

23 Panunggalan, 896 CE (Sarkar 1971:lviii).

24 Taji Gunung, 910 CE (Sarkar 1972:lxxx).

25 Tĕlang I and II, 904 CE (Suhadi and Soekarto 1986:2.6.1 and 2.6.2).

26 Kuți, c. $910 \mathrm{CE}$. The date equating to $840 \mathrm{CE}$ in this garbled late copy is an error (Boechari 1986:16-21).

27 See the inscription of Poh, 905 CE (Sarkar 1972:lxvi).

28 See, for instance, Kubukubu, 905 CE (Boechari 1986:155-159).

29 Kubukubu, CE 905 (Boechari 1986:155-159); Wanua Tĕngah III (Djoko 1986; Wisseman Christie 2001: 29-31).
} 
his grandmother in the area to the north of Magelang, because the previous benefice had been wiped out by such an eruption. The charter of the new benefice ends with an extended curse formula, reviving that used by rake Kayuwangi during a period of acute stress, calling not only upon the major and minor Hindu gods, but also the 'deified ancestors who protect the palace of the king of the state of Java.' ${ }^{30}$

That year was one of intense activity on Balitung's part. He endowed several other shrines associated with mountains, notably those on the slopes of the volcanoes Sumbing and Sundoro, devoted to the mountain spirits. ${ }^{31}$ This particular charter ends with a curse formula that places even greater emphasis upon the ancestors. It drops reference to Hindu gods altogether, and instead calls upon indigenous spirits, including the holy ones of old (hyang pürwwa), the purified servants, the floating fire - those guardian spirits, ancient ones, holy master spirits who have gone before, who held dominion over communities, lords of sanctuaries, builders of palaces ...those holy ancestors of Mḍang, of Poh Pitu, the great ones of Mataram: sang ratu Sañjaya, śrì mahärāja rakai Panangkaran, ...Panunggalan, ...Warak, ...Garung, ...Pikatan, ...Kayuwangi, ...Watu Humalang.... This list includes only those earlier kings judged to have been successes. The failures were not accorded guardian ancestor status, even if they achieved apotheosis after death.

The sense of unease clearly continued in the state after the eruption of 907 CE. In the following year Balitung was advised to revive the benefices of all the Buddhist foundations of the state in order to secure the stability of the throne. ${ }^{32}$ This approach seems not to have produced the desired results, since charters issued in $910 \mathrm{CE}$ returned to appeals to ancestor and mountain spirits. One of these called upon spirits inside Mt. Wilis, associated with the 'holy Fire' (hyang api), for protection. ${ }^{33}$ And the Kuți inscription of the same period ends with a curse calling upon Śiva and the spirits of holy places of volcanoes, including Dieng, Śataśrngga, Merapi, Sumbing and Sundoro, along with the holy spirits of Mdiang. ${ }^{34}$ By this time the ancestral palace site of Mḍang/ Madang had become famous enough for its name to have been given to a place in Luzon in the northern Philippines, at the farthest reaches of Java's sphere of influence. ${ }^{35}$

\footnotetext{
$30 \quad$ Rukam, 907 CE (Nastiti et al. 1982:23-28).

31 Mantyāsih I, 907 CE (Sarkar 1972:lxx).

32 Wanua Tĕngah III, 908 CE (Djoko 1986; Wisseman Christie 2001:29-31).

33 Pĕnampihan, 910 CE (Sarkar 1971:lix).

34 Kuți, c. 910 CE (Boechari 1986:16-21).

35 Laguna, 900 CE (Postma 1991).
} 
Although rake Hino $p u$ Dakșa succeeded to the throne uneventfully in 910 $\mathrm{CE}$, he clearly inherited a troubled state. He, too, appealed to the ancestors. While Balitung had emphasized the link between guardian ancestors and volcanoes, Dakșa focused more exclusively upon the ancestor kings themselves - 'those who formerly ruled the world'. ${ }^{36}$ Like Balitung, he honored rake Kayuwangi, ${ }^{37}$ and he also venerated Balitung. ${ }^{38}$ More importantly, however, he brought to the fore the early eighth-century founder of Mataram, sang ratu Sañjaya. Not only did he grant a benefice to the lineage temple of the descendants of Sañjaya, ${ }^{39}$ he went so far as to date four of his twelve surviving inscriptions in the Sañjaya era $^{40}$ - the first break in Mataram's history with the otherwise universally used Indian Śaka era.

Dakșa's use of the Sañjaya era suggests an attempt to maintain political unity through reinforcing connections with a legitimizing past - a step beyond appealing to guardian ancestors of the state. This move appears to reflect the deliberate construction of a foundation myth for the state focused upon a founder-ancestor. Although none of his successors followed his rather extreme example, ancestors remained a major theme in the inscriptions of succeeding kings.

Rake Layang dyah Tlodhong mounted to the throne in $919 \mathrm{CE}$ - again apparently unopposed. Yet he, too, felt the need to link himself to past rulers. His first recorded act was to endow his father's funerary shrine, ${ }^{41}$ and the next, to settle a dispute concerning a grant made by the revered former ruler rake Kayuwangi. ${ }^{42}$ In fact, almost all of his charters involved shrines connected with ancestor figures, who were described in one charter as 'those who were made holy ancestors of old',43 highlighting the apotheosis of the dead. Most of these ancestors were connected with the Saivite sanctuaries of Dieng or of other volcanic uplands of central and east Java.

Tlodhong's inscriptions returned to the nagging problem of geological instability. His curses called upon not only Hindu gods and royal ancestor spirits, but also the nāgarāja, the serpent kings, 'who in the depths make firm the sacred mountains. ${ }^{44}$ In Hindu mythology, these nāgarāja were inhabitants of

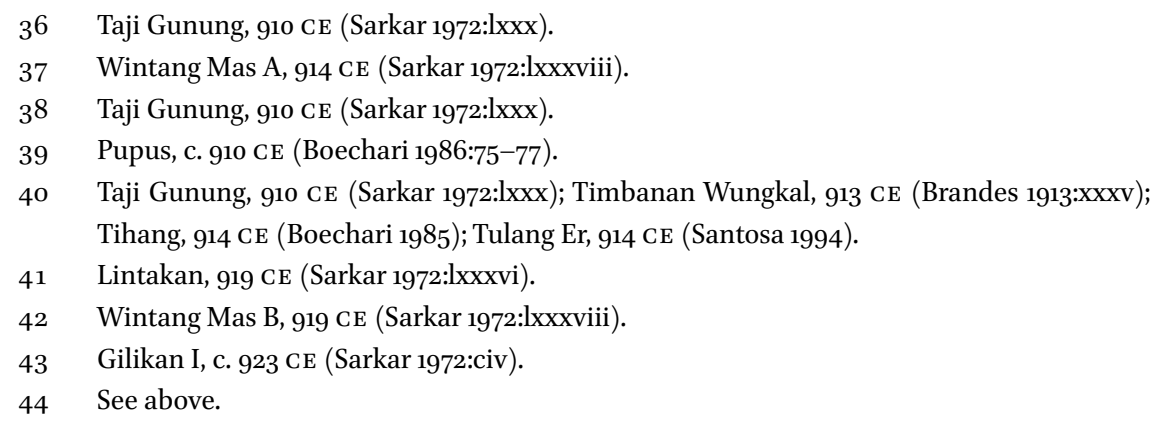


the caves of inaccessible mountains: when the nägaräja yawns, the earth trembles, and when he vomits fire he destroys (Daniélou 1964:308, 163). Wrapped around mount Mandara (or Meru), a nāgaräja provided the means by which the gods and demons churned the ocean of milk to produce amrta, the elixir of life (Zoetmulder 1968:308-309). These Hindu serpent kings, associated both with the stability and the agitation of mountains, were absorbed into the array of spirits governing the stability of Java's mountains. One manifestation of this appropriation is the central figure in the tenth century water temple Jalatundia on the slopes of Mt. Penanggungan in east Java - a water spout in the form of a nine-peaked lingga-mountain encircled by a nāgarāja (Bosch 1961:52).

Geological instability may explain why the next ruler, who came to the throne in around $927 \mathrm{CE}$, was displaced before the end of that year. The first act of his successor, rake Sumba dyah Wawa, was to reconfirm a grant made by his recently deceased predecessor, described as 'lying at Kayu Ramya', but not accorded the apotheosis title of dewata, ${ }^{45}$ perhaps reflecting his failure as a guardian figure. Wawa then went on to have a Śivamanḍala constructed to 'gain recognition by the holy spirits (hyang)' 46 Such constructions, performed in connection with ceremonies for the dead, are mentioned in the Agastyaparwwa (Gonda 1933-36:336.16, 380.7). The early tenth-century Śaivite version of the Sang Hyang Kamahāyānikan also lists the Śivamaṇạala amongst the vehicles for the attainment of heaven (Chandra 1997:19, 6a). It seems likely that this particular ceremony was held to promote the apotheosis of Wawa's own father, mentioned at the beginning of the charter as 'lying at Alas', but not yet bearing the title of dewata.

These two inscriptions were apparently the last to be issued in central Java. Although Wawa issued at least eight other charters during his two-year reign, all of these were in east Java. This burst of grant issuing, and the shift of geographical focus to east Java, may reflect not only the lure of the increasingly prosperous east Javanese ports, but also instability and uncertainty in central Java. Curse formulas again became prominent in the charters, even those issued in east Java - another sign of unease. These imprecations called upon both Śiva and ancestor spirits - 'those who are known to protect the palace of the king of Mdang in the state of Mataram. ${ }^{47}$ Wawa's charters that placed the most emphasis upon the guardians of the ancestral palace of Mdang were those farthest removed from its original site. They may have been paving the way for a shift of the palace to the east as the situation deteriorated in central Java.

\footnotetext{
45 Wangwang Bangĕn, 927 CE (Boechari 1986:14-16).

46 Wulakan, $928 \mathrm{CE}$ (Sarkar 1972:xciv).

47 Sangguran, 928 CE (Sarkar 1972:xcvi); Kampak, 928-929 CE (Brandes 1913:lii).
} 
This period of growing unease came to a head in 929 CE. Wawa was succeeded by his heir-apparent, rake Hino pu Siṇdok. Although more than twentyfive inscriptions survive from Siṇ̣ok's twenty-year reign, none was issued in central Java. In fact, it appears that no inscriptions were issued in central Java by the state of Mataram after $928 \mathrm{CE}$. A catastrophe of some sort must have occurred there. Most of the officials listed in Wawa's administration also appear in the early inscriptions issued by Sindok in east Java, suggesting that political breakdown was not the problem. And no other power is recorded as having moved into the heartland of central Java to replace the court following its shift to east Java. Since, as noted above, low-lying sites of this period lie under several layers of volcanic mud, it seems most likely that this catastrophe was caused by a major eruption - or series of eruptions - of Merapi, the volcano closest to the old heart of the state.

Sindok began his reign in east Java by issuing a rapid burst of benefice grants to religious foundations, apparently in an effort to establish authority and stability. The eight surviving charters issued during his first year on the throne were focused upon ancestor shrines linked to Śaivite gods, holy water foundations and mountains. ${ }^{48}$ The curse formulas of these charters called upon the protection not only of Śiva and the deified ancestors who 'protect the palace of the king of the state of Mataram', but also of the 'Nāgarājas, the serpent kings, whose encircling coils stabilize the sacred mountains'. ${ }^{49}$

Sindok again moved the palace, to Tamwlang, in $929 \mathrm{CE},{ }^{50}$ possibly in an attempt to escape bad luck in a time of political turmoil. He seems not to have succeeded, since two years later he was forced not only to reward clients who had provided military aid to secure his seat on the throne, but also to attempt to enhance his image by presenting himself as 'the manifestation of the Sun embodied as the god Śivāditya' ${ }^{51}$ Despite his unprecedented assumption of deified status while still alive, he appears to have failed to stabilize the state, since in $933 \mathrm{CE}$ he was still rewarding clients for military aid. ${ }^{52}$

Consequently, by $934 \mathrm{CE}$, Siṇ̣ok's charters began to direct resources towards a series of religious establishments that were, as before, lineage temples focused upon ancestors of the royal family, but now no longer purely Śaivite in nature. Siva and Buddha were merged in several foundations - some new, some

\footnotetext{
48 These include Gulunggulung, 929 CE (Nakada 1990:2-21); Linggasuntan, 929 CE (Nakada 1990:21-33); Cunggrang, 929 CE (Stutterheim 1925); Jĕrujĕru, 930 CE (Nakada 1990:33-51).

49 Turyyan, 929 CE (De Casparis 1988).

5o See above.

51 Waharu IV, 931 CE (Boechari 1986:59-65).

$5^{2}$ Gĕwĕg, 933 CE (Brandes 1913:xlv).
} 
converted to this new syncretic mode. ${ }^{53}$ This increasing syncretism was accompanied by an emphasis upon tantric knowledge and asceticism, as expressed in the Buddhist/Śaivite treatise Sang Hyang Kamahāyannikan, attributed to his reign. ${ }^{54}$ The imprecation formulas of the charters continued to call upon the guardian ancestor kings. In addition, at least two of these foundations were focused upon amrta, the elixir of life, ${ }^{55}$ and charged directly with praying for the security of the throne. These endowments paralleled those of temples linked to the holy water temple at Walandit, where the focus of worship was the major volcano Mt. Bromo. ${ }^{56}$ Despite these attempts to find a formula that would provide stability, Sinḍok was apparently forced to move the palace yet again - to Watu Galuh - by $943 \mathrm{CE},{ }^{57}$ where he appears at last to have achieved some sort of security for himself and his successors, since the palace settled there for the next 40 years. ${ }^{58}$

Sindiok's reign, which ended in about $948 \mathrm{CE}$, was apparently a difficult one. The loss of the old central Javanese heartland clearly cast its shadow over its early years. The fact that the state remained troubled through most of his reign may reflect not only the profundity of that loss, but continuing geological turbulence. The dearth of charters issued by his immediate successors and the stable site of his final palace, however, suggest that a degree of internal peace had returned to both the state and its environment.

This apparent political stability lasted for little over half a century, until the state suffered the next period of misfortune. By the beginning of the eleventh century, the state was yet again under attack - this time, in $1016 \mathrm{CE}$, by forces led by haji Wurawari of Lwarām, who burned the palace and killed the king and a large portion of the court. The record of this disastrous attack, and its aftermath, is contained in the Pucangan charter, issued in $1041 \mathrm{CE}$ by the dead king's successor Airlangga ${ }^{59}$ - who accords his deceased predecessor the status of dewata, despite his defeat. Although Airlangga managed to reassemble the state, it broke down yet again in civil war following his death in about $1048 \mathrm{CE}$, and remained divided until the thirteenth century. Whether geological instability

\footnotetext{
53 Hĕring, 934 CE (Brandes 1913:xlvii).

54 See Kats (1910) for the Buddhist version; Chandra (1997) for the Śaivite version.

55 Añjuklaḍang, 937 CE (Brandes 1913:xlvi); Sobhāmṛta, 939 CE (Cohen Stuart 1875:xxii, plates I and 3: for the other 4 plates, unpublished ms by Wisseman Christie 2003 and Titi Surti Nastiti 2004).

56 See Muñcang, 944 CE (Brandes 1913:li).

57 Paradah II, 943 CE (Brandes 1913:xlviii).

58 See Bandar Alim I, 985 CE (Suhadi and Richadiana 1997:2.10.1).

59 See Kern (1885); Brandes (1913:lxii); Poerbatjaraka (1941); for revised date, see Damais (1952:64), n. 2.
} 
played a role in Mataram's final breakdown is uncertain, although the east Javanese water temple of Walaṇit - apparently dedicated to an ancestor figure (dewata) and associated with the active volcano Bromo - first mentioned in a charter of Sindok, ${ }^{60}$ continued to be a focus of veneration in succeeding centuries. $^{61}$

\section{Conclusion}

Power politics in early Java were as turbulent as they were in many places at the time, but they were played out in a physical environment that was both more fertile and more unstable than most. Volcanic activity, in particular, has influenced the politics of the island for centuries. The contents of inscriptions surviving from the late first and early second millennia CE cast an oblique, but useful, light on the effect of environmental stress upon one of the island's early states - that of Mataram - and of the uses made of religion in generating and sustaining political stability.

A state, to survive, requires the security not only of stable institutions, but also of unifying ritual and myth - and Mataram survived for over 300 years, at times in the face of considerable odds. Of the three centuries of Mataram's existence, it was during the years between 847 and $948 \mathrm{CE}$ that the state's resilience was most severely tested. Yet, although it apparently abandoned its original core region in central Java during the second quarter of the tenth century, the state continued to exist into the middle of the eleventh century (Wisseman Christie 2001). Examined against the background of apparent geological instability, certain trends in the charters issued by Mataram's rulers between 847 and $948 \mathrm{CE}$ become significant. By the end of Sindok's reign in $948 \mathrm{CE}$, the process - begun under rake Kayuwangi a century before - of merging imported Buddhist and Hindu gods with indigenous ancestor spirits had produced a syncretic formulation that was still recognizable centuries later. The upheavals of the ninth and tenth centuries also produced a state foundation myth and ideology linked to venerated ancestors and volcanoes that persisted even longer. The institutions that Mataram had formed in good times remained durable, and in bad times - even during the state's catastrophic truncation - its religious and ideological framework proved to be adaptable.

\footnotetext{
6o See Lingasuntan, 929 CE (Brandes 1913:xxxix).

61 See the Walaṇit charter of 1405 CE (Brandes 1899:64-69).
} 